\title{
Sobre o Registro de Immoveis
}

\author{
J. A. C.
}

Dispunha o decreto n. ${ }^{\circ}$ 169-A, de 19 de Janeiro de 1890 , art. 8, § 4: A transcripção não induz a prova do dominio, que fica salvo a quem fôr".

Dessa disposição se deduz que a transcripção que não assentava em titulo legitimo não transferia o dominio. Si o immovel não pertencia ao alienante, o registro do titulo não produzia effeito; ao verdadeiro dono da cousa alienada ficava sempre salvo o direito de reivindical-a do poder de terceiro, ainda que de bôa fé.

A transcripção não gerava nem presumpção juris tantum da existencia do dominio na pessoa que figurava como adquirente. Na acção de reivindicação, por exemplo, o autor que houvesse obtido o dominio por um modo derivado, precisava provar que aquelle que lhe alienara a cousa era della proprietario ao tempo da transferencia, o que o forçava á investigação sobre acquisições anteriores até pelo menos o tempo necessario para formar o usucapião.

O Codigo Civil alterou a citada regra do decr. 169-A, prescrevendo no art. 859: "Presume-se pertencer o direito. real á pessoa em cujo nome se inscreveu ou transcreveu". Segue-se dahi que o adquirente se torna proprietario por força exclusiva da transcripção, independentemente de um titulo valido? Não, certamente. A presumpção do art. 859 cede á prova em contrario; ella não constitue prova formal absoluta do dominio. 
Nos termos do art. 860, o verdadeiro titular do direito póde exigir o cancellamento de uma transcripção injustificada, isto é, de uma transcripção que não se baseia em titulo legitimo, para o effeito de restabelecer a situação justa.

Mas então, perguntar-se-á, qual o alcance da innovação do Codigo? 0 alcance está nas consequencias da presumpção do art. 859. Aquelle que figura no registro de immoveis como proprietario reputa-se ter esse direito até que a prova da inexactidão do registro seja produzida (aqui tratamos só da propriedade, mas o principio estende-se aos outros direitos reaes).

$O$ reivindicante com base na transcripçåo em seu nome triumphará, si o reu não illidir a presumpção della resultante, provando a invalidade do titulo, etc.

Não vão além os effeitos da innovação do art. 859. Entretanto, segundo doutrina geralmente acceita, o Codigo adoptou o systema germanico em materia de transcripção com todas as suas consequencias. Por essa opinião o registro de um titulo de dominio se tem como exacto e completo em favor de terceiros adquirentes de bôa fé, por outros termos, aquelle que adquiriu um immovel fiado na exactidão do registro, torna-se proprietario, ainda que o immovel realmente não pertencesse ao alienante; de sorte que, nesse caso, o prejudicado (art. 860) disporá apenas da acção pessoal de indemnização ou de enriquecimento illegitimo (conforme a hypothese) contra quem de direito.

Ora, ao que nos parece, si o legislador brasileiro entendeu que com a presumpção do art. 859 introduziu essas innovações em nosso direito, confundiu cousas muito distinctas.

A lei allemã e os que a seguiram neste assumpto, como a suissa, distinguem a presumpção resultante da transcripção, da fé publica devida ao registro.

No Codigo allemão a presumpção é estabelecida pelo artigo 891 nestes termos: "Si um direito é inscripto em favor de alguem no registro predial, presume-se que esse direito lhe pertence. Si um direito inscripto no registro predial for cancellado, presume-se que elle não mais existe". 
A fé devida ao registro consta do art. 892: "Si alguem adquiriu por acto juridico um direito sobre um immovel ou um direito sobre esse direito, o conteúdo do registro predial se reputa exacto em seu proveito, salvo se tiver sido inscripta qualquer opposição á legalidade da inscripção ou si a inexactidão desta, era conhecida do adquirente..."

Os arts 937, 973 e 974 do Codigo suisso correspondem áquellas duas disposições do Codigo allemão.

Os commentadores dos dois codigos elucidam o assumpto, mostrando as consequencias da presumpção e as da fé publica.

O legislador brasileiro sanccionou o primeiro principio, mas omittiu o segundo. Logo, cumpre interpretar sem restricções o art. 860, isto é, o prejudicado terá acção de rectificação do registro, ainda que o immovel tenha sido alienado a terceiros de bôa fé por quem figurava indevidamente como dono na transcripção. Cumulando o pedido de rectificação com o da entrega da cousa, elle fará cair a alienação com os seus consectarios menos os que se ligarem á posse de bôa fé.

Soccorrem-se alguns na sustentação da doutrina contraria aos arts. 648, 796 § Unico, 850, 967 e 968 do Codigo Civil, mas é facil ver que nenhum desses dispositivos contém applicação do art. 859.

Tem-se invocado tambem a legislação civil de Portugal; mas a doutrina e a jurisprudencia alli tem vacillado muito diante do art. 149 do regulamento do registro predial de 1870 , no qual se estabelece presumpção analoga á do Codigo brasileiro, art. 859.

Em summa, si o legislador queria garantir os terceiros adquirentes de bôa fé contra as pretenções dos prejudicados pelas infidelidades do registro, devia ter consignado essa protecção em disposição expressa. Não o tendo feito, applica-se á materia o art. 860 combinado com os principios geraes, do que decorrem consequencias diversas do que teriam tido em mira os autores do Codigo Civil.

N. da R. - Respeitada a ortografia do autor. 